\title{
EVERYTHING IS NOT AWESOME. A LEGO BRICK AS A 3D TRADEMARK
}

by

RAFAŁ SKIBICKI

This paper discusses the reasoning of the trade mark protection of the flagship Lego products, the rectangular brick and the Lego minifigure, from the perspective of European Union trade mark system and the Polish legal system. This paper tries to answer two questions, on the basis of the discussed Lego cases and CJEU case law. Firstly, as I ask in the introduction, is trade mark protection an option for the products that were protected before with a patent? And, secondly, if the answer on the first question is positive, are there some legal obstacles other than these specified expressis verbis in trade mark law for obtaining such a protection? This paper is divided into eight parts. After the introduction, there is a brief history of the Lego company, its brick and its minifigure. It is mostly the story of their legal protection - from patents, through copyrights till trade marks. Third and fourth parts deal with the most important absolute grounds for refusal related to $3 D$ marks - the lack distinctiveness and the necessity to obtain technical character. Fifth chapter traces back to the Lego story, but this time with focus on their more actual legal problems with trade mark law. in sixth and seventh chapters moving on to the second question posed above, the attention is put to the hidden monopoly effect of the trade mark and the public domain dylemma. Finally, in the eight chapter I drew the final conclusions. All these considerations are presented mostly with the use of doctrinal method with the addition of comparative approach of the Polish and CJEU case law.

rafal.skibicki@uwr.edu.pl, University of Wrocław, Faculty of Law, Administration and Economics, Research Centre for Legal and Economic Issues of Electronic Communication, Poland. 


\section{KEY WORDS}

3D, Trade mark, Copyright, LEGO, Brick, Patent, Functionality, Non-conventional trade marks

\section{INTRODUCTION}

In 2014 LEGO became the largest toy company in the world. ${ }^{1}$ Naturally this date is not a coincidence, it is the year when Lego company released their long awaited the Lego Movie, which hit the box office with astonishing $\$ 468$ million revenue. ${ }^{2}$ However, the most of Lego company revenues still come from typical Lego sets ${ }^{3}$, from which Lego company (and, as was shown in the recent research, Lego investors on the second-hand market) ${ }^{4}$ receives a significant portion of their income. But what is the most remarkable about Lego, is that they have been selling the same product since 1958, which would be impossible for Hasbro or Mattel, Lego's main competitors in the toy industry. ${ }^{5}$ It is really phenomenal that one's sons or daughters can play with the same bricks and the same minifigures that their grandparents played with.

What is more, the Lego brick is also a unique object that carries within the evolution of worldwide intellectual property. Due to time limits of patent protection Lego has sought to keep their privileged position on the toy market by using all available aspects of the intellectual property system copyright, design law and finally trade marks) ${ }^{6}$. However, every action has its equal opposite reaction, therefore Lego company unleashed a series of legal proceedings across the globe. In other words, such a worldwide success would not be possible without the whole intellectual property protection system that the Lego company was and is using.

1 Davidson, J. (2014) Lego Is Now the Largest Toy Company in the World. [online], Money. Available from: http://money.com/money/3268065/lego-largest-toy-company-mattel/ [Accessed 15 April 2019].

2 IMDB. (2019) IMDb: the Lego Movie. [online], IMDB. Available from: https://www.imdb.com/title/tt1490017/ [Accessed 15 April 2019].

3 LEGO, (2018) Annual Report, Billund: LEGO A/S. p.29, Available from: https://www.lego.com/en-us/aboutus/lego-group/annual-report [Accessed 15 April 2019].

4 Dobrynskaya, V. and Kishilova, J. (2018) LEGO - the Toy of Smart Investors. April, Available from: https://papers.ssrn.com/sol3/papers.cfm?abstract_id=3291456 [Accessed 13 April 2019].

5 The Nacelle Company. (2018) the Toys That Made Us, Season 2, Episode -1 LEGO. [film] Available from: https://www.netflix.com/pl/title/80161497 [Accessed 26 March 2019].

6 Hunter, D. and Thomas, J. (2016) Lego and the system of intellectual property, 1955-2015, Intellectual Property Quarterly, 4, p. 1, Available from: https://ssrn.com/abstract=2743140 [Accessed 1 April 2019]. 
Nowadays the world is changing very fast and, in my opinion, the same happens to the Intellectual Property system. The boundaries between the various IP protection systems (patents, trade marks, copyrights, etc.) are increasingly blurred. It is due to a time limits of specific protection system. It should not be a surprise that every entrepreneur tries to maximise his profits. Therefore, when one protection system will expire (e.g. patents) its owners will try find another (e.g. copyright or trade mark). Examples of such products, just to mention those examined by CJEU, are many: Rubik's cube (it discovers intersections of trade marks and patents) ${ }^{7}$, Brompton bicycle (patent and copyright) ${ }^{8}$ or Trip-Trap chair (copyright and trade mark $)^{9}$. In my paper I would like to address this issue, but, knowing that it is definitely a vast topic, to look on it mainly from the perspective of the most important absolute ground for refusal in trade mark law the distinctive character and the shape of goods necessary to obtain a technical result. Furthermore, when dealing with the intersections of patent and the trade mark laws, I will refer this issue to the public domain doctrine.

What is more, taking into consideration that example is better than percept, I would like to address this issue is inconnection with the flagship Lego products - the rectangular brick and the Lego minifigure. Though the same issues were raised before the CJEU and the Polish Supreme Court in the cases of Lego brick trade mark, I will compare both verdicts with their legal surroundings - the EU trade mark regulations and the Polish law on trade marks. the Polish verdict could be especially interesting, because it was rendered on the eve of Polish accession to the EU, almost decade before CJEU Lego brick case. What is more, the Polish law thread was not yet widely discussed outside Poland. ${ }^{10}$

I would like to begin this paper with posing two questions that I would like to answer. Firstly, regarding the issue if trade mark protection isoption for at least some of the products that were protected before with a patent.

Judgment of 10 November 2016, Simba Toys GmbH \& Co. KG v. EUIPO, C-30/15 P, ECLI:EU:C:2016:849.

8 Judgment of 11 June 2020, SI, Brompton Bicycle Ltd v Chedech/Get2Get, C-833/18, ECLI:EU:C:2020:461.

9 Judgment of 18 September 2014, Hauck GmbH \& Co. KG v Stokke A/S and Others, C205/13, ECLI:EU:C:2014:2233.

10 See e.g. the only predeceasing approach to this topic: Brancusi L., (2016), the functionality of three-dimensional trade marks in the Polish practice, Zeszyty Naukowe Uniwersytetu Jagiellońskiego, Prace z prawa własności intelektualnej, (2(132)), pp. 20-31. 
Secondly, if the answer for first question is positive, whether there be some legal obstacles other than written directly in trade mark law?

\section{THE STORY OF LEGO AND ITS PROTECTION}

It all begun on the $28^{\text {th }}$ of January, 1958 , when a tiny family company from Billund applied for a patent over a plastic brick with eight studs. ${ }^{11}$ The name of this company - Lego - is abbreviation of the two Danish words "leg godt", which means "play well". ${ }^{12}$ Some authors say that in Latin it means "I put together" ${ }^{\prime 13}$, but it is not very likely that Ole Kirk Kristiansen, the founder of Lego company, was inspired by that.

Though the first Lego bricks were not different from the outside from their present form, they lacked one very important feature - they were hollow on the inside. It had a huge impact on their usability, because they stacked, but did not stick. ${ }^{14}$ Every building created with them could easily fall apart. And that was a moment to innovate. so the game-changer for the Lego company were the tubes underneath the brick. ${ }^{15}$ It allowed the Lego company to grant their toys better stability with more, how it was called later, "clutch power". ${ }^{16}$

Lego applied for patent protection for the standard brick with 8 studs in numerous countries including Denmark ${ }^{17}$, the United Kingdom ${ }^{18}$ and the United States, for which they received the US Patent no. 3,005,282 on the $24^{\text {th }}$ of October, $1961^{19}$.

It is hard to imagine that Lego registered their minifigures almost 20 years after applying for their first brick patent. They filed for their first minifigure patent in 1977, and did not launch the first set until $1978 .^{20}$

11 Hunter, D. and Thomas, J. (2016) Lego and the system of intellectual property, 1955-2015, Intellectual Property Quarterly, 4, p. 1, Available from: https://ssrn.com/abstract=2743140 [Accessed 1 April 2019].

12 Mortensen, T. F. (2017) the LEGO Group History, LEGO. [Online] Available from: https://www.lego.com/en-us/aboutus/lego-group/the_lego_history [Accessed 17 March 2019].

13 National Geographic. (2011) LEGO FACTS [online] National Geographic. Available from: https://www.nationalgeographic.com.au/history/lego-facts.aspx [Accessed 18 March 2019].

14 the Nacelle Company. (2018) the Toys That Made Us, Season 2, Episode -1 LEGO. [film] Available from: https://www.netflix.com/pl/title/80161497 [Accessed 26 March 2019].

15 Ibid.

16 Ibid.

17 Christiansen, G. K. (1962) Denmark, Patent No. 92683.

18 Christiansen, G. K. (1964) the United Kingdom, Patent No. 866577.

19 Christiansen, G. K. (1961) US, Patent No. 3,005,282. 
${ }^{\text {at }}$ the same time it was successfully registered in various countries like Denmark $^{21}$, the United Kingdom ${ }^{22}$ and the United States ${ }^{23}$.

But nothing lasts forever, especially patent protection, which has always been limited in time. Due to the expiration of patent for the standard brick in the late 1970s and early 1980s, Lego had to face their first crisis of intellectual property. ${ }^{24}$ First of all, they tried using their copyright against their competitors and accusing them of unfair competition, but it proved rather ineffective. ${ }^{25}$ Undoubtedly, it was one of the reasons that brought Lego to the trade mark protection. Another one was the trade mark's relative time limit, which allows the right holder to extend protection for subsequent ten years periods, theoretically indefinitely. Nevertheless, Lego chose a risky way to protect their products. Filing for the registration of a 3D trade mark consisting of the popular Lego brick caused many legal controversies, among which two took the main part. Distinctiveness of such a trade mark was the first, and technical functionality of the mark was the second.

\section{COULD A BRICK BE DISTINCTIVE? THE DISTINCTIVE CHARACTER OF 3D TRADE MARKS}

The most important feature of each trade mark is its distinctiveness. A mark consisting exclusively of a shape of goods will be protected only if such a shape is perceived not only as particular goods but also as a product source identifier ${ }^{26}$. It must identify the product and/or services in respect of which registration is applied for as originating from a particular undertaking, and thus to distinguish that product from those of other undertaking $\mathrm{s}^{27}$. If a mark is devoid of distinctive character, the other

\footnotetext{
${ }^{20}$ Tran, A. (2018) LEGO Minifigure Patents for Various Countries. [online] TheBrickFan. Available from: https://www.thebrickfan.com/lego-minifigure-patents-for-variouscountries/ [Accessed 1 April 2019].

21 Christiansen and Al. (1980) Denmark, Patent No. 140394.

22 Christiansen and Al. (1982) the United Kingdome, Patent No. 2006028

23 Christiansen and Al. (1980) USA, Patent No. 4,205,482.

24 Hunter, D. and Thomas, J. (2016) Lego and the system of intellectual property, 1955-2015, Intellectual Property Quarterly, 4, p. 6, Available from: https://ssrn.com/abstract=2743140 [Accessed 1 April 2019].

25 Ibid.

26 Kur A., Sentfleben M. (2017) European Trade Mark Law. a Commentary, Oxford: Oxford University Press, p. 149.

27 EUIPO, Trade mark guidelines, Part B. Examination, Sec. 4. Absolute grounds for refusal, Chapter 3.Non-distinctive trade marks (Article 7(1)(b) EUTMR), 1. General Remarks.
} 
absolute grounds for refusal will not be examined. ${ }^{28}$ Neither the Polish Industrial Property Law ${ }^{29}$ nor the previous Directive 2008/95/EC ${ }^{30}$ precisely specify what the distinctive character is and to what extent a trade mark should have it. Art. 1291(1)(2) of PIPL only indicates that the trade mark must be capable of distinguishing the goods for which it has been applied. This absolute ground for refusal is expressed a little bit differently that the one set out in the art. $7(1)$ (b) Regulation 2017/1001 13 and in the art. 4 (1) (b) of the current Directive 2015/2435 $5^{32}$. They both state the same: trade marks which are devoid of any distinctive character shall not be registered. Consequently, it would seem that such a trade mark shall have at least a minimal amount of distinctive character. ${ }^{33}$ It should also apply equally both to the Directive 2015/2435 (and before Directive 2008/95/EC) and Regulation 2017/1001, ${ }^{34}$ and consequently, due to the need to interpret countries' acts in compliance with directives, the requirement of having at least a minimal distinctive character should also apply to Polish trade marks. ${ }^{35}$

In addition, the distinctive character must be "assessed, first, by reference to the goods or services in respect of which registration has been sought and,

${ }^{28}$ Skubisz, R. and Mazurek, M. Względne podstawy odmowy udzielenia prawa ochronnego na znak towarowy (2017) In: Ryszard Skubisz (ed.) System Prawa Prywatnego Tom 14B Prawo Własności Przemysłowej. 2nd ed. Warszawa: C. H. Beck, p. 726.

29 The act of 30 June 2000 - Industrial Property Law (Dz.U. z 2017 r. poz. 776, as amended), Poland. Warszawa. in Polish, hereinafter: PIPL.

30 Directive 2008/95/EC of the European Parliament and of the Council of 22 October 2008 to approximate the laws of the Member States relating to trade marks, Official Journal of the European Union (OJ L 299/15) 8 November. Available from: https://eurlex.europa.eu/legal-content/EN/ALL/?uri=CELEX\%3A32008L0095 [Accessed 31 March 2019], hereinafter as Directive 2008/95/EC.

31 Regulation (EU) 2017/1001 of the European Parliament and of the Council of 14 June 2017 on the European Union Trademark, Official Journal of the European Union (OJ L 154/1), 16 June. Available from: https://eur-lex.europa.eu/legal-content/EN/ALL/?uri=CELEX \%3A32017R1001 [Accessed 31 March 2019], hereinafter as Regulation 2017/1001.

32 Directive (EU) 2015/2436 of the European Parliament and of the Council of 16 December 2015 to approximate the laws of the Member States relating to trade marks, Official Journal of the European Union (OJ L 336/1), 23 December. Available from: https://eurlex.europa.eu/legal-content/EN/TXT/?uri=CELEX\%3A32015L2436 [Accessed 31 March 2019], hereinafter as Directive 2015/2435.

33 Judgment of 29 April 2004, Henkel KGaa v. OHIM, C-456/01 P, EU:C:2004:258, paragraph 42.

${ }^{34}$ Judgment of 19 September 2002, DKV Deutsche Krankenversicherung AG v. OHIM, C104/00 P, EU: C:2002:506, paragraphs 13-25.

35 Skubisz, R., (2015) the acquired distinctive character of a trade mark as a consequence of its use (grounds, dates and proof of use). Biatostockie Studia Prawnicze, 19, p. 205, See also: Szczepanowska-Kozłowska, K., (2017) Bezwzględne przeszkody rejestracji znaku towarowego, In: Ryszard Skubisz (ed.) System Prawa Prywatnego Tom 14B Prawo Własności Przemystowej. Warszawa: C. H. Beck, p. 669. 
second, by reference to the perception of them by the relevant public ${ }^{\prime \prime 36}$. Furthermore, such a relevant public consists of consumers of the goods or services in question, who are reasonably well informed and reasonably observant and circumspect. ${ }^{37}$ Even before joining the EU, Polish courts settled a similar case law. Among them the crucial role was played by the Polish Supreme Court, which pointed out in 2003 that a spatial trade mark would have the distinctive character when the average consumer in the ordinary course of business transactions would be able to individualize the product on the market in relation to a specific producer. ${ }^{38}$

That thought was the starting point in the reasoning of the CJEU, which assumed that "only a mark which departs significantly from the norm or customs of the sector and thereby fulfils its essential function of indicating origin is not devoid of any distinctive character ${ }^{\prime \prime 39}$. Otherwise, it will not be possible to grant a legal protection to the three-dimensional mark. ${ }^{40}$

However, it does not mean that stricter criteria than those used for other categories of marks should be applied when assessing whether a three-dimensional mark is distinctive ${ }^{41}$. in any event, it must be determined whether such a mark enables the average consumer to distinguish without particular consideration being given to the distinction between the goods concerned and those from other companies. ${ }^{42}$

As the above considerations show, the formulation of one general principle which makes it possible to clearly decide on the possession of the distinctive character by a 3D mark is almost impossible. It must be

36 Judgment of 24 May 2012, Chocoladefabriken Lindt \& Sprüngli AG v OHIM, C-98/11 P, EU: C: 2012:307, paragraph 41 .

37 Judgment of 12 January 2006, Deutsche SiSi-Werke GmbH \& Co. Betriebs KG v OHIM, C173/04 P, EU:C:2006:20, paragraph 25.

38 "Kirkbi" A/S Billund v. Urząd Patentowy RP (2003). III RN 240/01, Supreme Court.

39 Judgment of 12 January 2006, Deutsche SiSi-Werke GmbH \& Co. Betriebs KG v OHIM, C173/04 P, EU:C:2006:20, paragraph 31. See also: Judgment of 7 October 2004, Mag Instrument Inc. v OHIM, C-136/02 P, EU:C:2004:592, paragraph 31; Judgment of 24 May 2012, Chocoladefabriken Lindt \& Sprüngli AG v OHIM, C-98/11 P, EU: C: 2012:307, paragraph 36; and Judgment of 7 May 2015, Voss of Norway ASa v OHIM, C-445/13 P, EU:C:2015:303, paragraph 91.

40 Wojcieszko-Głuszko, E., (2010) Zdolność rejestrowa wspólnotowych przestrzennych znaków towarowych (przegląd orzecznictwa). Zeszyty Naukowe Uniwersytetu Jagiellońskiego. Prace Z Prawa Własności Intelektualnej, (4 (110)), pp. 131-155.

41 Kur A., Sentfleben M., (2017) European Trade Mark Law. a Commentary, Oxford: Oxford University Press., p. 150.

42 Judgment of 7 October 2004, Mag Instrument Inc. v OHIM, C-136/02 P, EU:C:2004:592, paragraph 32; See also: Judgment of 7 May 2015, Voss of Norway ASa v OHIM, C-445/13 P, EU:C:2015:303, paragraph 92. 
assessed each time specifically, judging by the trade mark itself and by marked goods or services. What is more, under no circumstances is it possible to make a presumption of lack of distinctive character of a 3D mark. as CJEU stated already in Linde, Winward, Rado judgment, marks comprising shapes of goods should not be treated differently from other marks ${ }^{43}$. On the other hand, it must be noted that according to the CJEU case-law only a mark that "departs significantly from the norms or customs of the sector and thereby fulfils its essential function of indicating origin, is not devoid of any distinctive character" ${ }^{\prime 4}$. Thus, it may be said that the bar of distinctiveness is somehow set higher for 3D marks.

However, Lego brick as well as Lego minifigure meet the abovementioned criteria for distinctiveness set out by European law and practice. Both of them are easily recognised by reasonable consumers. It is even visible in the Polish or English language in which the particular type of bricks with studs on their surface are called Lego bricks, or simply Lego. The same goes for the Lego minifigure. Finally, it was also settled by CJEU verdicts $^{45}$ and OHIM decisions ${ }^{46}$, that they have both become distinctive as a consequence of their usage, and therefore they could serve as the indication of the source of origin of the goods. ${ }^{47}$

Surprisingly, the Polish Supreme Court did not agree with the CJEU verdict on the distinctive character of a Lego brick. What is more, the Polish court was very categorical and stated that "the spatial form that is a reflection of the commodity and conditioned solely by functional properties has no primary distinctiveness and cannot acquire the distinctiveness required for the registration of the trade mark". ${ }^{48}$ Thus, the Polish Supreme Court somehow mixed both lack of distinctiveness and functionality of Lego brick mark, as it excluded the possibility of acquiring distinctiveness through use of such a mark. It must be stated that the abovementioned judgement of Polish court based on the Act on Trade Marks of 31 January 1985 (hereinafter referred to as the TMA) which was in force until 21 August 2001 and which did not

43 Judgment of 8 April 2003, joined cases Linde AG, Winward Industries Inc., Rado Uhren AG, C-53/01 to C-55/01, EU:C:2003:206.

44 Judgment of 12 February 2004, Henkel v. OHIM, C-218/01 P, EU:C:2004:88, paragraph 52.

45 Judgment of 14 September 2010, Lego Juris A/S v OHIM, C-48/09 P, EU:C:2010:516; Judgment of 16 June 2015, Best-Lock (Europe) Ltd v OHIM, T-395/14, EU:T:2015:380.

46 Decision of 4 April 2014, Best-Lock (Europe) Ltd. v. LEGO Juris A/S, R 1896/2013-4; Decision of 10 July 2006, Best-Lock (Europe) Ltd. v. OHIM, R 856/2004-G.

47 Judgment of 14 September 2010, Lego Juris A/S v OHIM, C-48/09 P, EU:C:2010:516, paragraph 40.

48 "Kirkbi" A/S Billund v. Urzad Patentowy RP (2003). III RN 240/01, Supreme Court. 
comprise any provisions for 3D signs with functional exemptions. at the same time, it did not contain provision letting marks acquire distinctiveness through use, but both legal doctrine and practice accepted such possibility ${ }^{49}$. Despite the fact that there were no special provisions dedicated to refusal of registration of 3D marks based on their functionality, it was considered that trade mark protection should always be refused due to the public interest if registration of such a mark impedes competition and, thus, descriptive signs, generic signs or signs carrying general information about goods, which were mostly to word signs, were such a signs which should be excluded from protection ${ }^{50}$. Since functional 3D marks were thought to aim to inform about functional features of a product, they could also be considered as devoid of distinctive character ${ }^{51}$. Thus, art. 7(2) of the TMA, which enumerated, inopen catalogue, cases of signs deprived of distinctive features, was commonly used to deny trade mark protection to 3D marks ${ }^{52}$ and that is it also happened to Lego brick, despite the fact that, as European courts judged later, it did have distinctiveness. With all probability today the judgement of the Polish Supreme Court would be based on the exclusion of the protection of 3D marks consisting exclusively of a shape having essentially technical function such as Lego brick and not on its lack of distinctiveness.

\section{A FUNCTIONAL PROBLEM OF THE "CLUTCH POWER"}

Due to the patent past of the Lego brick and minifigure, the greatest threat for registering them as a trade mark was absolute ground for refusal called the sign which consists exclusively of goods necessary to obtain a technical result. It now exists almost in every jurisdiction, definitely including the Polish and EU trade mark systems. Till the 16th of March, 2019, the aforementioned absolute ground for refusal in PIPL was implementing Directive 2008/95/EC and thus was somewhat different than in the current Directive 2015/2435, as it was referring only to the shape of the sign, without even a single reference to another characteristic appearing in both the Directive 2015/2435 and the Regulation 2017/1001. Now, the difference

49 Skubisz R., (1990) Prawo znaków towarowych. Komentarz, Warszawa: Wydawnictwo Prawnicze, p.33.

50 Brancusi L., (2016), the functionality of three-dimensional trade marks in the Polish practice, Prace z prawa własności intelektualnej, (2(132)), pp. 20-31.

51 Ibid.

52 Ibid. 
has been settled, and PIPL at last complies with the EU regulations. However, as mentioned above, it was not included in Polish law before the entry into force of PIPL but it did not prevent the Polish Supreme Court from the refusal of protection of the Lego brick.

To begin with, it is of utmost importance to settle ratio legis of this absolute grounds for refusal. It was indicated by the ECJ for the first time in case C-299/99, where it was emphasized that this ground for refusal is set to: "prevent trade mark protection from granting its proprietor a monopoly on technical solutions or functional characteristics of a product which a user is likely to seek in the products of competitor ${ }^{\prime \prime 53}$. Moreover, it is no coincidence that among all rights in the field of broadly understood industrial property law only trade mark protection can be extended for subsequent periods. It seems to be quite justified that by expressing such opinion, the ECJ wanted to draw attention to the different character of functions performed by trade marks in relation to functions of patents or industrial designs. However, it must be borne in mind that when a consumers actually perceive a shape of goods as a source identifier (and I do not have doubts that this is the case with the Lego brick) and they rely on this shape as a badge of origin when purchasing goods, they may be misled by identical or similar products stemming from another undertaking ${ }^{54}$. But, as will be mentioned later, Lego and others in similar situation may use other legal means to fight with such unfair competition.

Despite the fact that the CJEU interpreted the concept of a sign consisting exclusively of the shape of the goods necessary to obtain a technical result, it still arouses many controversies. According to the Société de Produits Nestlé Sa v. Cadbury UK Ltd case "it must be interpreted as referring only to the manner in which the goods at issue function and it does not apply to the manner in which the goods are manufactured." 55 . in other words, the production methods will not be relevant for the assessment of the product's properties either. However, there are two crucial words in art. 7(1)(e)(ii) EUTMR and "technical" is none of them. The words that are the most vague and the most powerful in the same time

53 Judgment of 18 June 2002, Koninklijke Philips Electronics NV v Remington Consumer Products Ltd., C-299/99, EU:C:2002:377, paragraph 78.

54 Kur A., Sentfleben M., (2017) European Trade Mark Law. a Commentary, Oxford: Oxford University Press. p. 158.

55 Judgment of 16 September 2015, Société de Produits Nestlé Sa v. Cadbury UK Ltd., C215/14, EU:C:2015:604, paragraph 46. 
are "exclusively" and "necessary" and it has not changed since the Lego brick judgement.

When it comes to the word "exclusively", the CJEU confirmed in its Lego judgement that minor non-functional arbitrary elements in functional shape were irrelevant and they did not change the fact that the whole shape was exclusively functional ${ }^{56}$. at the same time, it was added that such a sign cannot be refused registration as a trade mark under that provision if the shape of the goods at issue incorporates a major non-functional element, such as a decorative or imaginative element which plays important role in the shape ${ }^{57}$. It must be stated that such approach of CJEU is considered as missing the fact that different degrees of functionality require different modes of trade mark protection ${ }^{58}$. Taking into account that nowadays design of products is so sophisticated that the border between functional and decorative elements of goods is more and more vague, the approach of CJEU should be more nuanced and deeper.

The word "necessary" also still needs clarification, despite the fact that CJEU approached this issue i.a. firstly in Philips and later in Lego judgements. as Lego tried to prove, the shape of their brick cannot be perceived as necessary, as there are alternative shapes using the same technical solution. ${ }^{59}$ Thus, it is not the only shape possible to use. However, CJEU, in my opinion, incorrectly, stated firmly that the existence of alternative shapes with the same functionality alone cannot be sufficient to exclude the application of this grounds for refusal ${ }^{60}$. the CJEU argument was that the trade mark holder could prevent competition from using not only the same mark, i.e. the same shape of product, but also similar marks creating likelihood of confusion, i.e. many alternative shapes. However, there are other solutions to such a risk. Why not restrict the protection of such a 3D marks to only identical marks and not to similar ones as G. Dinwoodie suggests ${ }^{61}$ ?

${ }^{56}$ Judgment of 14 September 2010, Lego Juris A/S v OHIM, C-48/09 P, EU:C:2010:516, paragraph 52.

57 Ibid.

58 Schober N., (2013), the Function of a Shape as an Absolute Ground for Refusal, IIC (44), pp. 35-62.

59 Judgment of 14 September 2010, Lego Juris A/S v OHIM, C-48/09 P, EU:C:2010:516, paragraph 32 .

${ }^{60}$ Judgment of 14 September 2010, Lego Juris A/S v OHIM, C-48/09 P, EU:C:2010:516, paragraph 54. 
Establishing clear borders of the scope of the abovementioned grounds for refusal is even more important taking into consideration the fact that it is such a strong exclusion from protection that such functional marks cannot acquire distinctiveness through use under EU law, as may be derived from art. 3 (3) of Directive 2008/95/EC (in the new directive 2015/2436 it is Article 4 (4)) and in art. 7 (3) of Regulation 2017/1001. This rule was also confirmed by the CJEU in the rich case law ${ }^{62}$.

All in all, this absolute ground for refusal is a reason why Lego brick trade mark was deemed invalid in many jurisdictions. ${ }^{63}$ a similar justification (based in part on the ruling in abovementioned Koninklijke Philips Electronics NV v. Remington Consumer Products Ltd case) was also indicated by the Polish Supreme Court and the CJEU in the LEGO brick cases. the Polish Supreme Court stated that the interest of business entities requires the exemption from registration of such signs. Their registration would lead to monopolisation, which, in effect, would seriously and without a justification limit the activities of other entrepreneurs ${ }^{64}$. Such opinion was also shared by CJEU, because it is undoubtedly certain that entrepreneurs should not be allowed to use trade mark law for unlimited prolongation of exclusive rights regarding technical solutions. ${ }^{65}$ It did not matter that Lego had tried hard to prove that the registration of 3D brick mark would not place competitors in a disadvantageous position ${ }^{66}$.

Lego was not the only one to face this kind of a problem. Very often companies tried to protect their position in the market after the expiration of their patents, de facto registering their product as a three-dimensional

${ }^{61}$ Dinwoodie G.B., (2020), Overlap and Redundancy in the Intellectual Property System: Trademark Always Loses, In: Austin G., Christie A., Kenyon A., Richardson M. (ed)., Across Intellectual Property: Essays in Honour of Sam Ricketson, Cambridge : Cambridge University Press, pp. 26-37.

62 Judgment of 18 June 2002, Koninklijke Philips Electronics NV v Remington Consumer Products Ltd., C-299/99, EU:C:2002:377, paragraph 57. See also: Judgment of 14 September 2010, Lego Juris A/S v OHIM, C-48/09 P, EU:C:2010:516, paragraph 47; Judgment of 20 September 2007, Benetton Group Spa v G-Star International BV., C-371/06, EU:C:2007:542, paragraph 26.

63 Nicotra, A., (2010) Chapter 9. Hitting the bricks. In: Christopher Heath, Anselm Kamperman Sanders Landmark Intellectual Property Cases and Their Legacy. Alphen aan den Rijn: Wolters Kluwer, pp. 135-180.

${ }^{64}$ "Kirkbi" A/S Billund v. Urząd Patentowy RP (2003). III RN 240/01, Supreme Court.

65 Judgment of 24 May 2012, Chocoladefabriken Lindt \& Sprüngli AG v OHIM, C-98/11 P, EU: C: 2012:307, paragraph 56.

${ }^{66}$ Judgment of 14 September 2010, Lego Juris A/S v OHIM, C-48/09 P, EU:C:2010:516, paragraph 30. 
trade mark. Every time, even in Rubik's case ${ }^{67}$ after the approval in first instance, CJEU expressly refused to use this institution for such a monopolistic purpose. The position of such enterprises on the market cannot be protected from competition by introducing faithful copies of the shape of the product to the market, which results from the application of the exact same solution. The registration of such a three-dimensional trade mark would grant such undertakings a monopoly on a given good or service. The case law emphasizes, however, that such violations may, if circumstances so require, be treated as acts of unfair competition. ${ }^{68}$ Therefore, entrepreneurs are not left without legal protection. on the contrary - in such situations they often use competition law.

\section{LEGO LEGAL BATTLES IN THE EU: MINIFIGURE AND THE LEGO BRICK}

Both the Lego minifigure and the Lego brick have a very long trade mark history, but there is one serious difference between the two of then - CJEU upheld the Lego minifigure protection, while deprived the Lego brick of the trade mark protection.

Nevertheless, both of them had a serious patent history. While in the case of the Lego brick CJEU stated that "protection of that shape as a trade mark once the patent has expired would considerably and permanently reduce the opportunity for other undertakings to use that technical solution" ${ }^{69}$, it was not a thing for Lego minifigure.

Furthermore, the General Court (hereinafter referred to as GC) and OHIM did not find any evidence for the technical functions, allowing the figure to be joined to the other building blocks. ${ }^{70}$ Moreover, the functionality was not found in the graphical representation of the hand of Lego minifigure. All in all, as GC assumed, "those elements cannot be held, either in view of the overall impression conveyed by the contested trade mark or as a result of the analysis of its constituent elements, to be the most important

67 Judgment of 10 November 2016, Simba Toys GmbH \& Co. KG v EUIPO, C-30/15 P, EU:C:2016:849.

68 Judgment of 14 September 2010, Lego Juris A/S v OHIM, C-48/09 P, EU:C:2010:516, paragraph 61.

69 Judgment of 14 September 2010, Lego Juris A/S v OHIM, C-48/09 P, EU:C:2010:516, paragraph 46.

70 Judgment of 16 June 2015, Best-Lock (Europe) Ltd v OHIM, T-395/14, EU:T:2015:380, paragraph 32. 
elements of that mark". ${ }^{71}$ These considerations were quite opposite to those regarding the Lego brick case. the CJEU found "that the most important element of the sign composed of the Lego brick consists in the two rows of studs on the upper surface of that brick" which led to the conclusion "that with the sole exception of its colour, all the other elements of the sign constituted by that brick are also functional". ${ }^{72}$ as it can be seen, both courts had a different point of view on perceiving the graphic representation of those trade marks. GC pointed out that we should not seek the functionality which is not visible on the representation of a trade mark, but CJEU gone further. It did not limit the functionality to the trade mark representation, because if doing so, it would be a completely useless brick (with studs on the top, but without tubes underneath it could not stick together). What is more, it even assessed the technical functionality by comparing the Lego brick trade mark to the previous patents descriptions ${ }^{73}$.

What is definitely worth mentioning is the relation of the Lego brick and the Lego minifigure, which in the eyes of the GC judges and OHIM experts "had nothing in common with the mark at issue in those proceedings except for the fact that it was a toy produced by the same company"74. at best, in my opinion, it is a slight misunderstanding, because they have a lot in common, they stick together on the basis of the same, once patented, mechanism. However, the Lego minifigure could be used or played with even without that mechanism. Its most important quality is its shape, yellow head, hands, legs and torso. It is possible to imagine a Lego minifigure without the "clutch power" and that would be impossible for the Lego brick, which without that feature would lose its utility. in other words, in Lego brick case we had a sign consisting "exclusively" of the shape of goods which was necessary to obtain a technical result, while in the case of the Lego minifigure it was not so clear.

\footnotetext{
71 Op. cit. paragraph 33.

72 Judgment of 14 September 2010, Lego Juris A/S v OHIM, C-48/09 P, EU:C:2010:516, paragraph 73.

73 Op. cit., paragraph 85.

74 Judgment of 16 June 2015, Best-Lock (Europe) Ltd v OHIM, T-395/14, EU:T:2015:380, paragraph 37.
} 


\section{THE HIDDEN MONOPOLY EFFECT OF THE LEGO BRICK TRADE MARK}

Many similarities and two differences can be found between the two cases. First of them was mentioned above, the second one had a greater impact on verdicts of many courts across the globe - it is the monopoly effect of granting trade mark protection to Lego brick. Mostly, it was connected with the problem of the sign functionality, but sometimes it was also accompanied by the lack of distinctive character ${ }^{75}$.

It was definitely the main obstacle for the Lego brick trade mark registration. What is more, it is not a rule explicitly expressed in the law. It had to be interpreted from the functionality absolute ground for refusal. as the Polish Supreme Court stated: "the interest of participants in business transactions requires the exemption from registration of such signs, because their registration would lead to the monopolization of the use of these signs by individual entrepreneurs, which would result in a very serious and unjustified restriction of the activities of other entrepreneurs" ${ }^{76}$. Then the CJEU stated: "the interest underlying Article 7(1)(e)(ii) of Regulation No 40/94 is to prevent trade mark law granting undertaking a monopoly on technical solutions or functional characteristics of a product" ${ }^{\prime 77}$. The same reasoning could be found in many other countries, for example in Canada, where the local Supreme Court stated: "the law of trade marks may not be used to perpetuate monopoly rights enjoyed under now-expired patents. the market for these products is now open, free and competitive" ${ }^{\prime 78}$. The worldwide trade mark law rule seems simple - trade mark should not protect goods once protected by expired patents.

It should not be forgotten that the Lego brick case happened in almost every country of the EU. ${ }^{79}$ Lego lost everywhere, except for Hungary. as a consequence, this company became a monopolist in this segment of the toy market in the whole country. ${ }^{80}$

\footnotetext{
"Kirkbi" A/S Billund v. Urzad Patentowy RP (2003). III RN 240/01 Supreme Court. Ibid.

77 Judgment of 14 September 2010, Lego Juris A/S v OHIM, C-48/09 P, EU:C:2010:516, paragraph 43.

78 Kirkibi AG v. Ritvik Holdings Inc." (2005). 2005 SCC 65, [2005] 3 SCR 302.

79 Nicotra, A., (2010) Chapter 9. Hitting the bricks. In: Christopher Heath, Anselm Kamperman Sanders Landmark Intellectual Property Cases and Their Legacy. Alphen aan den Rijn: Wolters Kluwer, pp. 170-175.

${ }_{80}^{80}$ Op. cit. p. 166.
} 


\section{IS THE DOCTRINE OF PUBLIC DOMAINOBSTACLE FOR REGISTERING 3D TRADE MARKS?}

It must be noted that Lego cases touched upon the issue of the relation between intellectual property rights and public domain. in my opinion, the actions of Lego aiming at obtaining trade mark protection for their products were quite similar to those regarding the Gustav Vigeland sculptures belonging to the public domain which Oslo Municipality tried to register as trade marks. The Norwegian Intellectual Property Office rejected such applications on the basis of public policy (art. 3(1)(f) of Directive 2008/95/EC), which was upheld by EFTA Court, that stated the registration of such a sign could be refused "if the sign consists exclusively of a work pertaining to the public domain and if registration of this sign would constitute a genuine and sufficiently serious threat to a fundamental interest of society" ${ }^{\prime 81}$.

Could the same reasoning be applied in the Lego brick case? One can argue that both Lego brick and the Vigeland's sculptures were once protected by intellectual property right that has expired, so now both of them should find their place in the public domain. What is more, this argument could also be strengthened withad maiori ad minus argumentation, due to a fact that copyright protections (ad maiori part) is longer than the patent protection (ad minus part). Therefore as it may seem, it is justified by a fact that patents, more than copyright, should provide incentive for a new production ${ }^{82}$. Furthermore, the patent protection gives enough time to protect goods from competition but it should not eliminate the competition for eternity. After patent expiration, the invention should become the part of the public domain in the name of technical and human development.

On the other hand, there is a difference in public policy between absolute ground for refusal regarding the cultural goods such as sculptures or paintings and absolute grounds for refusal in relation with products. The risk of monopoly in toy business is a serious thing, but not every time it would be "genuine and sufficiently serious threat to a fundamental interest of society".

\footnotetext{
81 Judgment of 6 April 2017, Municipality of Oslo, E-5/16, paragraph 102.

82 Bently, L., Sherman B., Gangjee D., Johnson P., (2018). Intellectual Property Law, $5^{\text {th }}$ edition. Oxford: Oxford University Press. p. 398.
} 
Therefore, in my opinion, Patent and Trade Mark Offices and courts should take into account the possible impact of the pending trade mark registration on the public domain. If the trade mark registration will have the same impact as the previous, expired patent, that belongs to a public domain, the registration should be declined on the basis of public policies and in the name of protecting the public domain.

Nonetheless, I am aware that this task is not so easy. to begin with, due to a territorial scope of the IP rights, there is not one public domain, but there are separate public domains in each country. It means that. especially when discussing the EU trade marks, there are 27 (excluding United Kingdom) public domains that should be taken into account. so while examining the trade mark applications, all of this state patents should be examined.

To sum up, the IP rights overlaps should be resolved with the deep analysis of the subject matter, with particular emphasis on the scope and the purpose of the applicable rights and freedoms ${ }^{83}$. All in all, the courts and the patent offices should act in the registration process as a guardians of the public domain in the benefit of the society ${ }^{84}$.

\section{SUMMARY}

The title of this chapter was extracted on purpose from "Everything is awesome", title song from "The Lego Movie" mentioned in the introduction. It could surely be the anthem of Lego's legal actions to protect its intellectual property. Unfortunately for the Lego company, the line "Everything is better when we stick together. Side by side, you and I gonna win forever, let's party forever $^{\prime 85}$ was stopped in the middle by the verdicts of courts which prevented Lego from winning forever. Nevertheless, the legal story of Lego brick and Lego minifigure is quite unique, because, as Hunter and Thomas noted: "it has evolved with the global intellectual property system, it has learnt how to make all the laws snap together, to build a fabulously successful and valuable creation" ${ }^{\prime \prime 6}$.

83 Peukert A., Doctrine of the Public Domain (2016). Forthcoming in: Josef Drexl (ed), the Innovation Society and Intellectual Property, EIPIN Series, Edward Elgar Publishing, Available at SSRN: https://ssrn.com/abstract=2713757 or http://dx.doi.org/10.2139/ssrn.2713757, marg. 35.

84 Op. cit. marg. 38.

85 Sara, Q., Tegan, Q. and the Lonely Island, (2017). EVERYTHING IS AWESOME!!!. [sound recording]. 
What is more, looking at the Lego brick cases (judged both by Polish Supreme Court and the CJEU), the evolution of case law on the distinctiveness and the technical function could also be observed. First of all, the spatial form, formerly based on expired patent, could be distinctive both originally and by acquiring dinstinctiveness ${ }^{87}$. Though, it is more difficult for the spatial form to be considered distinctive than other, more "standard" (i.e. graphic or word marks) trade marks, because it must "depart significantly from the norms or customs of the sectors" ${ }^{88}$. Secondly, there is also the issue of the necessity of using the shape applied for trade mark protection to obtain a technical result, preventing the rightsholder from obtaining a proprietor monopoly on a technical solutions ${ }^{89}$. When the registration will lead to such a monopoly connected with the unlimited prolongation of exclusive rights (e.g. patents) it should be denied.

All things considered, answering briefly on the first question posed in the introduction, it must be stated that the trade mark protection for such products, formerly protected by patents, could be given, though under two conditions fulfilled together: first, distinctiveness of such a shape which could be achieved by its significant departure from the norms or customs of the sector and the fact that registration will not give the applicant a technical monopoly, similar to the one he had so far thanks to the expired patent.

However, not only those two requirements should stand in a way of registering the 3D trade mark that was protected in past by patent. Not only the thread of creating monopoly should be taken into consideration while examining the application for such a trade mark, but also its impact on the public domain. Those arguments are, in my opinion, connected as in their core they have the same goal - they should not stop the technical development. Both courts and patent and trademark offices should bear in mind this idea while deciding about registration or cancelation.

Those arguments are especially visible when comparing the Lego brick and the Lego minifigure cases. Why was the first trade mark rejected, while the second one was upheld? The reason for it are the competitors

\footnotetext{
86 Hunter D., Thomas J., 31 Lego Brick (2019) In: Claudy Op Den Kamp and Dan Hunter (ed.) a History of Intellectual Property in 50 objects. Cambridge: Cambridge University Press, p. 263.

${ }^{87}$ Judgment of 14 September 2010, Lego Juris A/S v OHIM, C-48/09 P, EU:C:2010:516, paragraph 40.

88 Judgment of 12 February 2004, Henkel v. OHIM, C-218/01 P, EU:C:2004:88, paragraph 52.

${ }^{89}$ Judgment of 18 June 2002, Koninklijke Philips Electronics NV v Remington Consumer Products Ltd., C-299/99, EU:C:2002:377, paragraph 78.
} 
of the Lego company as it was possible for them to create their own minifigures (as e.g. Cobi, Megablocks or Bestlock did), but it would be impossible to continue their business activity without the possibility to use the same basic brick that Lego created.

To sum up, it seems that there are many safeguards that should not be removed while discussing the protection of $3 \mathrm{D}$ trade marks such as Lego brick or minifigure. If the current law is applied strictly and in line with well-established case law, the danger of the extension of expired patent protection in disguise of as a trade mark will be minimal. Thanks to that, the trade mark protection can be awesome once more.

\section{LIST OF REFERENCES}

[1] Kirkbi" A/S Billund v. Urząd Patentowy RP (2003). III RN 240/01 Supreme Court.

[2] Bently, L., Sherman B., Gangjee D., Johnson P., (2018). Intellectual Property Law, 5th edition. Oxford: Oxford University Press.

[3] Brancusi L., (2016), The functionality of three-dimensional trade marks in the Polish practice, Prace z prawa własności intelektualnej, (2(132)), pp. 20-31.

[4] Christiansen and Al. (1980) Denmark, Patent No. 140394.

[5] Christiansen and Al. (1980) USA, Patent No. 4,205,482.

[6] Christiansen and Al. (1982) the United Kingdome, Patent No. 2006028.

[7] Christiansen, G. K. (1961) US, Patent No. 3,005,282.

[8] Christiansen, G. K. (1962) Denmark, Patent No. 92683.

[9] Christiansen, G. K. (1964) the United Kingdome, Patent No. 866577.

[10] Davidson, J. (2014) Lego Is Now the Largest Toy Company in the World. [online], Money. Available from: http://money.com/money/3268065/lego-largest-toy-companymattel/ [Accessed 15 April 2019].

[11] Decision of 10 July 2006, Best-Lock (Europe) Ltd. v. OHIM, R 856/2004-G.

[12] Decision of 4 April 2014, Best-Lock (Europe) Ltd. v. LEGO Juris A/S, R 1896/2013-4.

[13] Dinwoodie G.B., (2020), Overlap and Redundancy in the Intellectual Property System: Trademark Always Loses, In: Austin G., Christie A., Kenyon A., Richardson M. (ed)., Across Intellectual Property: Essays in Honour of Sam Ricketson, Cambridge: Cambridge University Press, pp. 26-37.

[14] Directive (EU) 2015/2436 of the European Parliament and of the Council of 16 December 2015 to approximate the laws of the Member States relating to trade marks, Official 
Journal of the European Union (OJ L 336/1), 23 December. Available from: https://eurlex.europa.eu/legal-content/EN/TXT/?uri=CELEX\%3A32015L2436

[Accessed 31 March 2019].

[15] Directive 2008/95/EC of the European Parliament and of the Council of 22 October 2008 to approximate the laws of the Member States relating to trade marks, Official Journal of the European Union (OJ L 299/15) 8 November. Available from: https://eurlex.europa.eu/legal-content/EN/ALL/?uri=CELEX\%3A32008L0095

[Accessed 31 March 2019].

[16] Dobrynskaya, V. and Kishilova, J. (2018) LEGO - the Toy of Smart Investors. April, Available from: https://papers.ssrn.com/sol3/papers.cfm?abstract_id=3291456 [Accessed 13 April 2019].

[17] EUIPO, Trade mark guidelines, Part B. Examination, Sec. 4. Absolute grounds for refusal, Chapter 3.Non-distinctive trade marks (Article 7(1)(b) EUTMR), 1. General Remarks.

[18] Hunter D., Thomas J., 31 Lego Brick (2019) In: Claudy Op Den Kamp and Dan Hunter (ed.) a History of Intellectual Property in 50 objects. Cambridge: Cambridge University Press, p. 256 - 263.

[19] Hunter, D. and Thomas, J. (2016) Lego and the system of intellectual property, 1955-2015, Intellectual Property Quarterly, 4, pp. 1-21, Available from: https://ssrn.com/abstract=2743140 [Accessed 1 April 2019].

[20] IMDB. (2019) IMDb: the Lego Movie. [online], IMDB. Available from: https://www.imdb.com/title/tt1490017/ [Accessed 15 April 2019].

[21] Judgment of 10 November 2016, Simba Toys GmbH \& Co. KG v EUIPO, C-30/15 P, EU:C:2016:849.

[22] Judgment of 11 June 2020, SI, Brompton Bicycle Ltd v Chedech/Get2Get, C-833/18, ECLI:EU:C:2020:461.

[23] Judgment of 12 February 2004, Henkel v. OHIM, C-218/01 P, EU:C:2004:88.

[24] Judgment of 12 January 2006, Deutsche SiSi-Werke GmbH \& Co. Betriebs KG v OHIM, C-173/04 P, EU:C:2006:20.

[25] Judgment of 14 September 2010, Lego Juris A/S v OHIM, C-48/09 P, EU:C:2010:516.

[26] Judgment of 16 June 2015, Best-Lock (Europe) Ltd v OHIM, T-395/14, EU:T:2015:380.

[27] Judgment of 16 September 2015, Société de Produits Nestlé Sa v. Cadbury UK Ltd., C215/14, EU:C:2015:604.

[28] Judgment of 18 June 2002 , Koninklijke Philips Electronics NV v Remington Consumer Products Ltd., C-299/99, EU:C:2002:377. 
[29] Judgment of 18 September 2014, Hauck GmbH \& Co. KG v Stokke A/S and Others, C205/13, ECLI:EU:C:2014:2233.

[30] Judgment of 19 September 2002, DKV Deutsche Krankenversicherung AG v. OHIM, C104/00 P, EU: C:2002:506.

[31] Judgment of 20 September 2007, Benetton Group Spa v G-Star International BV., C371/06, EU:C:2007:542.

[32] Judgment of 24 May 2012, Chocoladefabriken Lindt \& Sprüngli AG v OHIM, C-98/11 P, EU: C: 2012:307.

[33] Judgment of 29 April 2004, Henkel KGaa v. OHIM, C-456/01 P, EU:C:2004:258.

[34] Judgment of 6 April 2017, Municipality of Oslo, E-5/16.

[35] Judgment of 7 May 2015, Voss of Norway ASa v OHIM, C-445/13 P, EU:C:2015:303.

[36] Judgment of 7 October 2004, Mag Instrument Inc. v OHIM, C-136/02 P, EU:C:2004:592.

[37] Judgment of 8 April 2003, joined cases Linde AG, Winward Industries Inc., Rado Uhren AG, C-53/01 to C-55/01, EU:C:2003:206.

[38] Kirkibi AG v. Ritvik Holdings Inc. (2005) 2005 SCC 65, [2005] 3 SCR 302.

[39] Kur A., Sentfleben M. (2017) European Trade Mark Law. a Commentary, Oxford: Oxford University Press.

[40] LEGO, (2018) Annual Report, Billund: LEGO A/S. p.29, Available from: https://www.lego.com/en-us/aboutus/lego-group/annual-report [Accessed 15 April2019].

[41] Mortensen, T. F. (2017) the LEGO Group History, LEGO. [Online] Available from: https://www.lego.com/en-us/aboutus/lego-group/the_lego_history [Accessed 17 March 2019].

[42] National Geographic. (2011) LEGO FACTS [online] National Geographic. Available from: https://www.nationalgeographic.com.au/history/lego-facts.aspx[Accessed 18March2019].

[43] Nicotra, A., (2010) Chapter 9. Hitting the bricks. In: Christopher Heath, Anselm Kamperman Sanders Landmark Intellectual Property Cases and Their Legacy. Alphen aan den Rijn: Wolters Kluwer, pp. 135-180.

[44] Peukert A., Doctrine of the Public Domain (2016). Forthcoming in: Josef Drexl (ed), the Innovation Society and Intellectual Property, EIPIN Series, Edward Elgar Publishing, Available at SSRN: https://ssrn.com/abstract=2713757 or http://dx.doi.org/10.2139/ssrn.2713757, marg. 35.

[45] Regulation (EU) 2017/1001 of the European Parliament and of the Council of 14 June 2017 on the European Union Trademark, Official Journal of the European Union (OJ L 154/1), 
16 June. Available from: https://eur-lex.europa.eu/legal-content/EN/ALL/?uri=CELEX \%3A32017R1001 [Accessed 31 March 2019].

[46] Sara, Q., Tegan, Q. and the Lonely Island, (2017). EVERYTHING IS AWESOME!!!. [sound recording].

[47] Schober N., (2013), the Function of a Shape as Absolute Ground for Refusal, International Review of Intellectual Property and Competition Law, volume (44), pp. 35-62.

[48] Skubisz R., (1990) Prawo znaków towarowych. Komentarz, Warszawa: Wydawnictwo Prawnicze.

[49] Skubisz, R. and Mazurek, M. Względne podstawy odmowy udzielenia prawa ochronnego na znak towarowy (2017) In: Ryszard Skubisz (ed.) System Prawa Prywatnego Tom 14B Prawo Własności Przemysłowej. $2^{\text {nd }}$ ed.Warszawa: C.H.Beck,p. 724-844.

[50] Skubisz, R., (2015) the acquired distinctive character of a trade mark as a consequence of its use (grounds, dates and proof of use). Białostockie Studia Prawnicze, 19, p. 203-227.

[51] Szczepanowska-Kozłowska, K., (2017) Bezwzględne przeszkody rejestracji znaku towarowego In: Ryszard Skubisz (ed.) System Prawa Prywatnego Tom 14B Prawo Własności Przemystowej. Warszawa: C. H. Beck, p. 638-723.

[52] The act of 30 June 2000 - Industrial Property Law (Dz.U. z 2017 r. poz. 776, as amended), Poland. Warszawa. in Polish.

[53] The Nacelle Company. (2018) the Toys That Made Us, Season 2, Episode -1 LEGO. [film] Available from: https://www.netflix.com/pl/title/80161497 [Accessed 26 March 2019].

[54] Tran, A. (2018) LEGO Minifigure Patents for Various Countries. [online] TheBrickFan. Available from: https://www.thebrickfan.com/lego-minifigure-patents-for-variouscountries/ [Accessed 1 April 2019].

[55] Wojcieszko-Głuszko, E., (2010) Zdolność rejestrowa wspólnotowych przestrzennych znaków towarowych (przegląd orzecznictwa). Zeszyty Naukowe Uniwersytetu Jagiellońskiego. Prace Z Prawa Własności Intelektualnej, (4 (110)), pp. 131-155. 